\title{
The influence of acetamiprid and chlorpyrifos on the biological activity entomopathogenic nematodes (Steinernematidae, Heterorhabditidae)
}

\author{
Wpływ acetamiprydu i chloropiryfosu na aktywność biologiczną \\ nicieni owadobójczych (Steinernematidae, Heterorhabditidae)
}

\author{
Katarzyna Kruk*, Magdalena Dzięgielewska
}

\begin{abstract}
Summary
The aim of the study was to assess the influence of various concentrations ( $0 \% ; 0.1 \% ; 0.3 \% ; 0.5 \% ; 1 \%$ ) of acetamiprid (Mospilan $20 \mathrm{SP}$ ) and chlorpyrifos (Dursban $450 \mathrm{EC}$ ) on the biological activity of entomopathogenic nematodes (Steinernema feltiae Filipjev Steinernema-System, Biopartner; Heterorhabditis bacteriophora Poinar-B-Green, Biopartner). After a 4-day contact of the nematodes with insecticides, their mortality, infectious ability and fertility was tested. Steinernema feltiae was more sensitive to used doses of plant protection products than $\mathrm{H}$. bacteriophora. Both species were more susceptible to chlorpyrifos than acetamiprid. As the pesticides concentration increased, the mortality of the nematodes increased, whereas their infectious ability and fertility reduced.
\end{abstract}

Key words: entomopathogenic nematodes, neonicotinoids, acetamiprid, chlorpyrifos, biological activity

\section{Streszczenie}

Celem przeprowadzonych badań była ocena wpływu różnych stężeń (0\%; 0,1\%; 0,3\%; 0,5\%; 1\%) acetamiprydu (Mospilan 20 SP) oraz chloropiryfosu (Dursban 450 EC) na aktywność biologiczną nicieni owadobójczych Steinernema feltiae Filipjev - Steinernema-System, Biopartner; Heterorhabditis bacteriophora Poinar - B-Green, Biopartner. Po czterodniowym kontakcie nicieni z insektycydami zbadano ich śmiertelność, zdolności infekcyjne oraz płodność. Steinernema feltiae wykazywał większą wrażliwość na testowane dawki środków ochrony roślin niż H. bacteriophora. Oba gatunki były bardziej podatne na działanie chloropiryfosu niż acetamiprydu. Wraz ze wzrostem stężenia badanych preparatów śmiertelność nicieni proporcjonalnie wzrastała, a zdolności infekcyjne i reprodukcyjne malały.

Słowa kluczowe: nicienie owadobójcze, neonikotynoidy, acetamipryd, chloropiryfos, aktywność biologiczna

\footnotetext{
Zachodniopomorski Uniwersytet Technologiczny w Szczecinie

al. Piastów 17, 70-310 Szczecin

*corresponding author: katarzyna.kruk@zut.edu.pl

ORCID: 0000-0003-3749-1504, 0000-0003-2866-2375
} 


\section{Wstęp / Introduction}

Wzrost intensyfikacji produkcji rolniczej, jak i zwiększenie zagrożenia ze strony agrofagów wynikające m.in. ze zmian klimatycznych wpływa na zwiększenie zużycia chemicznych środków ochrony roślin. Do najczęściej i najpowszechniej stosowanych środków owadobójczych w Polsce należą neonikotynoidy i insektycydy fosforoorganiczne (Rozkrut 2020). Stosowane w rolnictwie preparaty z tych grup chemicznych charakteryzują się wysoką skutecznością w zwalczaniu szkodników roślin, jednak nie pozostają obojętne dla środowiska m.in. dla organizmów pożytecznych występujących w agrocenozach (Sunanda i wsp. 2016; Pisa i wsp. 2017). Zasady integrowanej ochrony roślin kładą nacisk na zwalczanie agrofagów za pomocą metod niechemicznych, do których należy m.in. metoda biologiczna (Jamiołkowska i wsp. 2017). W biologicznym zwalczaniu owadów szkodliwych coraz częściej wykorzystuje się nicienie owadobójcze (EPNs) z rodziny Steinernematidae i Heterorhabditidae, których naturalne występowanie w agrocenozach na terenie naszego kraju zostało wielokrotnie potwierdzone (Bednarek 1990; Jaworska i Dudek 1992; Tomalak 2005; Matuska i Kamionek 2008; Ropek i Nicia 2008; Dzięgielewska 2012; Tumialis i wsp. 2016).

W ostatnich latach ze względu na większe zainteresowanie ekologią środowiska rolniczego przeprowadzono wiele badań dotyczących wpływu pestycydów na organizmy pożyteczne (Pisa i wsp. 2017). Większość z nich dotyczy zapylaczy oraz innych stawonogów, ale pojawia się coraz więcej pozycji literaturowych omawiających zagadnienie wpływu różnych grup pestycydów na organizmy glebowe m.in. nicienie owadobójcze (Peters i Poullot 2004; Gutiérrez i wsp. 2008; Laznik i wsp. 2012; Ulu i wsp. 2016; Laznik i Trdan 2017). Z wielu badań wynika, że insektycydy fosforoorganiczne i neonikotynoidy wpływają na zwiększenie śmiertelności, a także zmniejszenie zdolności infekcyjnych i reprodukcyjnych EPNs (Chen i wsp. 2003; Dzięgielewska i Kaup 2007; Nermut i Mráček 2010; Kwizera i Susurluk 2017). Wysoka śmiertelność pożytecznych nicieni po kontakcie z insektycydami aplikowanymi do środowiska rolniczego utrudnia skuteczne stosowanie metod biologicznych w walce ze szkodnikami roślin, w zestawieniu z metodami chemicznymi. Dlatego opracowanie metody umożliwiającej jednoczesne stosowanie różnych metod ochrony roślin przed szkodnikami wymaga znajomości interakcji zachodzących pomiędzy substancjami czynnymi lub żywymi organizmami zawartymi w preparatach wykorzystywanych w ochronie roślin. Sprecyzowanie bezpiecznych okresów karencji dla aplikacji biopreparatów po wcześniejszym wykonaniu zabiegów chemicznych czy dobór odpowiednich insektycydów bezpiecznych dla określonych organizmów pożytecznych np. nicieni owadobójczych stają się niezbędne dla skutecznego ich wykorzystania w walce biologicznej przeciwko szkodnikom. Dodatkowo aplikacja pestycydów do środowiska rolniczego nie pozostaje obojętna dla lokalnych populacji pożytecznych organizmów występujących w agrocenozach i naturalnie wpływających na szkodliwe owady, w tym nicienie. Innym elementem istotnym dla opłacalnej produkcji rolniczej jest skuteczność stosowanych metod ochrony przed szkodnikami, które powinny uzupełniać się, a nie wykluczać.

Celem przeprowadzonych badań było określenie wpływu wybranych insektycydów z grupy neonikotynoidów (acetamipryd) oraz preparatów fosforoorganicznych (chloropiryfos) na aktywność biologiczną, w tym zdolności infekcyjne oraz płodność dwóch gatunków nicieni owadobójczych Steinernema feltiae Filipjev i Heterorhabditis bacteriophora Poinar, pochodzących z biopreparatów (Steinernema-System i B-Green firmy Biopartner) rekomendowanych w ochronie roślin przed szkodnikami.

\section{Materiały i metody / Materials and methods}

W badaniach testowano wpływ dwóch insektycydów opartych na acetamiprydzie (Mospilan 20 SP) i chloropiryfosie (Dursban 480 EC) na aktywność biologiczną larw inwazyjnych (J3) dwóch gatunków nicieni owadobójczych: S. feltiae (Steinernema-System, Biopartner) i H. bacteriophora (B-Green, Biopartner). W badaniach zastosowano różne stężenia insektycydów $(0 \% ; 0,1 \% ; 0,3 \% ; 0,5 \% ; 1 \%)$ oraz jedną dawkę ( $5 \mathrm{ml}$ ) preparatów (według zaleceń producentów zawartych w kartach testowanych biopreparatów). Próbę kontrolną stanowiła woda destylowana. Badania wykonano $\mathrm{w}$ trzech powtórzeniach dla każdego z przyjętych wariantów: S. feltiae + Mospilan $20 \mathrm{SP}(0,1 \% ; 0,3 \% ; 0,5 \%$; $1 \%)$, S. feltiae + Dursban 480 EC (0,1\%; 0,3\%; 0,5\%; 1\%), S. feltiae + woda destylowana, H. bacteriophora + Mospilan 20 SP $(0,1 \% ; 0,3 \% ; 0,5 \% ; 1 \%), H$. bacteriophora + Dursban 480 EC $(0,1 \% ; 0,3 \% ; 0,5 \% ; 1 \%)$, H. bacteriophora + woda destylowana.

W pierwszym etapie badań testowano śmiertelność nicieni względem wybranych preparatów. W każdym powtórzeniu wykorzystano 3000 larw inwazyjnych nicieni. Kontrole wykonywano co 24 h, do czwartego dnia badania. Następnie po trzykrotnym przepłukaniu larw wodą destylowaną analizowano ich zdolności infekcyjne względem testowanych owadów Galleria mellonella L. W tym celu larwy infekcyjne (J3) S. feltiae i H. bacteriophora (300 larw J3 na każdą gąsienicę $G$. mellonella) zaaplikowano na bibułę filtracyjną na szalkę Petriego $(\varnothing=10 \mathrm{~cm})$, po czym umieszczono na niej po 10 gąsienic $G$. mellonella, w 3 powtórzeniach. Stopień zarażenia owadów przez nicienie kontrolowano co 24 godziny, przez 4 dni. Wynik wyrażono jako łączny odsetek zarażonych gąsienic w stosunku do wszystkich testowanych owadów w toku czterodniowego doświadczenia. W końcowym etapie badań zarażone nicieniami gąsieni- 
ce G. mellonella przeniesiono na odwrócone szkiełko zegarkowe (White 1927) i przetrzymywano w temperaturze pokojowej $\left(22-24^{\circ} \mathrm{C}\right)$ przez 10 dni w przypadku $S$. feltiae i 14 dni w przypadku $H$. bacteriophora. Po tym czasie obserwowano migrację nowego pokolenia larw inwazyjnych nicieni (J3) do wody. Na podstawie ich liczebności określono wydajność końcową po przejściu pełnego cyklu życiowego w ciele gąsienic G. mellonella. Uzyskane wyniki badań poddano analizie statystycznej z wykorzystaniem programu STATISTICA 13.3. Przeprowadzono test istotności różnic dla średnich śmiertelności obydwu gatunków nicieni przyjmując poziom różnic $\mathrm{p}<0,05$ jako wysoce istotny.

\section{Wyniki i dyskusja / Results and discussion}

Na podstawie uzyskanych wyników stwierdzono zależności między śmiertelnością larw inwazyjnych $S$. feltiae i H. bacteriophora, a czasem ich ekspozycji w różnych stężeniach testowanych insektycydów (Mospilan 20 SP oraz Dursban 480 EC) (tab. 1, 2). Dłuższy czas ekspozycji oraz wyższe stężenie substancji czynnej zwiększało śmiertelność larw nicieni. Larwy S. feltiae wykazały wyraźnie wyższą wrażliwość na acetamipryd (Mospilan 20 SP) w porównaniu z larwami $H$. bacteriophora (tab. 1). Statystycznie istotne różnice $(\mathrm{p}<0,05)$ zaobserwowano już przy stężeniu $0,3 \%$ insektycydu Mospilan 20 SP po 24-godzinnym kon-

Tabela 1. Średnia śmiertelność larw inwazyjnych nicieni Steinernema feltiae i Heterorhabditis bacteriophora [\%] po kontakcie $\mathrm{z}$ insektycydem Mospilan $20 \mathrm{SP}$ w różnych stężeniach [\%]

Table 1. The average mortality of infective juvenile stage of Steinernema feltiae and Heterorhabditis bacteriophora [\%] after contact with Mospilan $20 \mathrm{SP}$ in various concentrations [\%]

\begin{tabular}{|c|c|c|c|c|c|c|c|c|c|}
\hline \multicolumn{10}{|c|}{ Mospilan 20 SP } \\
\hline \multicolumn{5}{|c|}{ Steinernema feltiae } & \multicolumn{5}{|c|}{ Heterorhabditis bacteriophora } \\
\hline \multirow{2}{*}{$\begin{array}{c}\text { Stężenie } \\
\text { preparatu } \\
\text { Concentration } \\
{[\%]}\end{array}$} & \multicolumn{4}{|c|}{$\begin{array}{l}\text { śmiertelność nicieni (J3) [\%] w czasie } \\
\text { mortality of nematodes }(\mathrm{J} 3)[\%] \text { in time }\end{array}$} & \multirow{2}{*}{$\begin{array}{c}\text { stężenie } \\
\text { preparatu } \\
\text { concentration } \\
{[\%]} \\
\end{array}$} & \multicolumn{4}{|c|}{$\begin{array}{l}\text { śmiertelność nicieni }(\mathrm{J} 3)[\%] \text { w czasie } \\
\text { mortality of nematodes }(\mathrm{J} 3)[\%] \text { in time }\end{array}$} \\
\hline & $24 \mathrm{~h}$ & $48 \mathrm{~h}$ & $72 \mathrm{~h}$ & $96 \mathrm{~h}$ & & $24 \mathrm{~h}$ & $48 \mathrm{~h}$ & $72 \mathrm{~h}$ & $96 \mathrm{~h}$ \\
\hline 0 & 0 & 2,3 & 5,8 & 9 & 0 & 0 & 2,3 & 3,25 & 4,3 \\
\hline 0,03 & 0,5 & 5,4 & 10,6 & 11 & 0,03 & 1,75 & 5,4 & 12,5 & 17,5 \\
\hline 0,1 & 8,7 & 16,9 & 24 & 31 & 0,1 & 6 & 10,9 & 20 & 29 \\
\hline 0,3 & $29,4^{*}$ & 31,6 & 40,9 & 41,4 & 0,3 & 12,5 & 15,5 & 31,1 & 34 \\
\hline 0,5 & $86,9 *$ & $88,5^{*}$ & $94,3^{*}$ & $95,5^{*}$ & 0,5 & 24 & 26,3 & 30,6 & 38,6 \\
\hline 1 & $100 *$ & $100^{*}$ & $100 *$ & $100^{*}$ & 1 & 31,9 & 49,3 & 68 & 76,4 \\
\hline
\end{tabular}

*śmiertelność larw inwazyjnych $S$. feltiae statystycznie istotnie wyższa niż $H$. bacteriophora $(\mathrm{p}<0,05)$

*mortality of infective juvenile stage of $S$. feltiae is statistically significantly higher than H. bacteriophora $(\mathrm{p}<0.05)$

Tabela 2. Średnia śmiertelność larw inwazyjnych nicieni Steinernema feltiae i Heterorhabditis bacteriophora [\%] po kontakcie z insektycydem Dursban 480 EC w różnych stężeniach [\%]

Table 2. The average mortality of infective juvenile stage of Steinernema feltiae and Heterorhabditis bacteriophora [\%] after contact with Dursban 480 EC in various concentrations [\%]

\begin{tabular}{|c|c|c|c|c|c|c|c|c|c|}
\hline \multicolumn{10}{|c|}{ Dursban 480 EC } \\
\hline \multicolumn{5}{|c|}{ Steinernema feltiae } & \multicolumn{5}{|c|}{ Heterorhabditis bacteriophora } \\
\hline \multirow{2}{*}{$\begin{array}{c}\text { Stężenie } \\
\text { preparatu } \\
\text { Concentration } \\
{[\%]}\end{array}$} & \multicolumn{4}{|c|}{$\begin{array}{l}\text { śmiertelność nicieni }(\mathrm{J} 3)[\%] \text { w czasie } \\
\text { mortality of nematodes }(\mathrm{J} 3)[\%] \text { in time }\end{array}$} & \multirow{2}{*}{$\begin{array}{c}\text { stężenie } \\
\text { preparatu } \\
\text { concentration } \\
{[\%]}\end{array}$} & \multicolumn{4}{|c|}{$\begin{array}{l}\text { śmiertelność nicieni }(\mathrm{J} 3)[\%] \mathrm{w} \text { czasie } \\
\text { mortality of nematodes }(\mathrm{J} 3)[\%] \text { in time }\end{array}$} \\
\hline & $24 \mathrm{~h}$ & $48 \mathrm{~h}$ & $72 \mathrm{~h}$ & $96 \mathrm{~h}$ & & $24 \mathrm{~h}$ & $48 \mathrm{~h}$ & $72 \mathrm{~h}$ & $96 \mathrm{~h}$ \\
\hline 0 & 0 & 2,3 & 5,8 & 9 & 0 & 0 & 2,3 & 3,25 & 4,3 \\
\hline 0,03 & 6 & 10,9 & 12,2 & 13 & 0,03 & 10,8 & 12,48 & 13,7 & 15,3 \\
\hline 0,1 & $78,2 *$ & $100^{*}$ & $100^{*}$ & $100 *$ & 0,1 & 10 & 18 & 20,8 & 29,7 \\
\hline 0,3 & $90,6^{*}$ & $93,5^{*}$ & $100 *$ & $100 *$ & 0,3 & 11,3 & 15,5 & 23,4 & 29,9 \\
\hline 0,5 & $100 *$ & $100 *$ & $100 *$ & $100 *$ & 0,5 & 16 & 32,1 & 34,6 & 50,6 \\
\hline 1 & $100 *$ & 100 & $100 *$ & 100 & 1 & 31,9 & 61,4 & 78,7 & 81,3 \\
\hline
\end{tabular}

*śmiertelność larw inwazyjnych $S$. feltiae statystycznie istotnie wyższa niż H. bacteriophora $(\mathrm{p}<0,05)$

*mortality of infective juvenile stage of $S$. feltiae is statistically significantly higher than H. bacteriophora $(\mathrm{p}<0.05)$ 
takcie larw nicieni z preparatem. Wraz ze wzrostem stężenia zwiększały się różnice $\mathrm{w}$ reakcji testowanych gatunków nicieni na acetamipryd. Przy stężeniu 0,5\% śmiertelność larw $S$. feltiae wyniosła $95,5 \%$ po czterech dniach doświadczenia, a w przypadku $H$. bacteriophora tylko 38,6\%. Natomiast zwiększenie dawki preparatu do stężenia 1\% skutkowało 100\% śmiertelnością larw S. feltiae już po upływie 24 godzin kontaktu z insektycydem i wyraźnym wzrostem śmiertelności u H. bacteriophora po 96 h kontaktu larw infekcyjnych z preparatem (76,4\%) (tab. 1).

Silniejszą reakcję $S$. feltiae w porównaniu z H. bacteriophora obserwowano przy kontakcie nicieni z chloropiryfosem zawartym w preparacie Dursban 480 EC. Statystycznie istotne różnice między dwoma gatunkami nicieni zaobserwowano już przy stężeniu 0,1\% i były one znacząco większe niż w przypadku acetamiprydu (tab. 1,2). Największą śmier- telność $H$. bacteriophora zaobserwowano po 96-godzinnym kontakcie z 1\% roztworem chloropiryfosu, i wyniosła ona 81,3\% (4,9\% więcej w porównaniu do acetamiprydu) (tab. 2).

Ponadto zauważono, że testowane gatunki nicieni różniły się wrażliwością na zastosowane insektycydy - neonikotynoid Mospilan 20 SP i preparat fosforoorganiczny Dursban 480 EC. Wyraźnie wyższą wrażliwość na chloropiryfos (Dursban 480 EC) niż acetamipryd (Mospilan 20 SP) wykazały larwy S. feltiae, których śmiertelność przy zastosowaniu dawki $0,1 \%$ była wyższa ponad trzykrotnie (tab. 1, 2). W przypadku $H$. bacteriophora największą różnicę zaobserwowano przy zastosowaniu dawki 0,5\% i wynosiła ona $12 \%$, jednak nie była statystycznie istotna (tab. 1,2).

Dawki zastosowanych środków ochrony roślin wpłynęły również na zdolności infekcyjne nicieni względem gąsienic G. mellonella (tab. 3, 4). Wraz ze wzrostem stężenia insek-

Tabela 3. Stopień zarażenia owadów pułapkowych Galleria mellonella przez nicienie owadobójcze po ekspozycji w różnych stężeniach insektycydu Mospilan 20 SP [\%]

Table 3. Infection rate of Galleria mellonella trap insects by entomopathogenic nematodes treated with various concentrations of Mospilan 20 SP [\%]

\begin{tabular}{|c|c|c|c|c|c|c|c|c|c|}
\hline \multicolumn{10}{|c|}{ Mospilan 20 SP } \\
\hline \multicolumn{5}{|c|}{ Steinernema feltiae } & \multicolumn{5}{|c|}{ Heterorhabditis bacteriophora } \\
\hline \multirow{2}{*}{$\begin{array}{c}\text { Stężenie } \\
\text { preparatu } \\
\text { Concentration } \\
{[\%]}\end{array}$} & \multicolumn{4}{|c|}{$\begin{array}{l}\text { zarażenie Galleria mellonella }[\%] \text { w czasie } \\
\text { infection rate of Galleria mellonella }[\%] \text { in time }\end{array}$} & \multirow{2}{*}{$\begin{array}{c}\text { stężenie } \\
\text { preparatu } \\
\text { concentration } \\
{[\%]}\end{array}$} & \multicolumn{4}{|c|}{$\begin{array}{l}\text { zarażenie Galleria mellonella }[\%] \mathrm{w} \text { czasie } \\
\text { infection rate of Galleria mellonella }[\%] \text { in time }\end{array}$} \\
\hline & $24 \mathrm{~h}$ & $48 \mathrm{~h}$ & $72 \mathrm{~h}$ & $96 \mathrm{~h}$ & & $24 \mathrm{~h}$ & $48 \mathrm{~h}$ & $72 \mathrm{~h}$ & $96 \mathrm{~h}$ \\
\hline 0 & 47 & 80 & 100 & 100 & 0 & 87 & 100 & 100 & 100 \\
\hline 0,03 & 0 & 10 & 37 & 80 & 0,03 & 0 & 63 & 83 & 83 \\
\hline 0,1 & 0 & 66 & 83 & 83 & 0,1 & 0 & 45 & 66 & 80 \\
\hline 0,3 & 0 & 5 & 45 & 55 & 0,3 & 0 & 53 & 73 & 80 \\
\hline 0,5 & 0 & 0 & 0 & 0 & 0,5 & 0 & 45 & 80 & 90 \\
\hline 1 & 0 & 0 & 0 & 0 & 1 & 0 & 45 & 50 & 55 \\
\hline
\end{tabular}

Tabela 4. Stopień zarażenia owadów pułapkowych Galleria mellonella przez nicienie owadobójcze po ekspozycji w różnych stężeniach insektycydu Dursban 480 EC [\%]

Table 4. Infection rate of Galleria mellonella trap insects by entomopathogenic nematodes treated with various concentrations of Dursban 480 EC [\%]

\begin{tabular}{|c|c|c|c|c|c|c|c|c|c|}
\hline \multicolumn{10}{|c|}{ Dursban 480 EC } \\
\hline \multicolumn{5}{|c|}{ Steinernema feltiae } & \multicolumn{5}{|c|}{ Heterorhabditis bacteriophora } \\
\hline \multirow{2}{*}{$\begin{array}{c}\text { Stężenie } \\
\text { preparatu } \\
\text { Concentration } \\
{[\%]}\end{array}$} & \multicolumn{4}{|c|}{$\begin{array}{l}\text { zarażenie Galleria mellonella [\%] w czasie } \\
\text { infection rate of Galleria mellonella }[\%] \text { in time }\end{array}$} & \multirow{2}{*}{$\begin{array}{c}\text { stężenie } \\
\text { preparatu } \\
\text { concentration } \\
{[\%]}\end{array}$} & \multicolumn{4}{|c|}{$\begin{array}{l}\text { zarażenie Galleria mellonella }[\%] \mathrm{w} \text { czasie } \\
\text { infection rate of Galleria mellonella [\%] in time }\end{array}$} \\
\hline & $24 \mathrm{~h}$ & $48 \mathrm{~h}$ & $72 \mathrm{~h}$ & $96 \mathrm{~h}$ & & $24 \mathrm{~h}$ & $48 \mathrm{~h}$ & $72 \mathrm{~h}$ & $96 \mathrm{~h}$ \\
\hline 0 & 47 & 80 & 100 & 100 & 0 & 87 & 100 & 100 & 100 \\
\hline 0,03 & 0 & 30 & 30 & 30 & 0,03 & 17 & 50 & 50 & 53 \\
\hline 0,1 & 0 & 0 & 0 & 0 & 0,1 & 0 & 10 & 45 & 45 \\
\hline 0,3 & 0 & 0 & 0 & 0 & 0,3 & 13 & 23 & 27 & 30 \\
\hline 0,5 & 0 & 0 & 0 & 0 & 0,5 & 0 & 10 & 15 & 15 \\
\hline 1 & 0 & 0 & 0 & 0 & 1 & 3 & 7 & 7 & 7 \\
\hline
\end{tabular}


tycydów zdolności infekcyjne nicieni malały. W przypadku acetamiprydu statystycznie istotne różnice między gatunkami nicieni zaobserwowano przy stężeniu 0,3\%; 0,5\% i 1\%, natomiast w przypadku chloropiryfosu przy stężeniu $0,03 \%$; 0,1\%; 0,3\% i 0,5\%. Zdolność zarażenia gąsienic G. mellonella przez $S$. feltiae była znacznie mniejsza w porównaniu do H. bacteriophora. Ponadto zauważono większy spadek zdolności infekcyjnej nicieni po kontakcie z chloropiryfosem w porównaniu do acetamiprydu (tab. 3, 4).

Testowane insektycydy wpłynęły również na zdolności reprodukcyjne nicieni, a analiza statystyczna uzyskanych wyników potwierdziła istotność różnic między próbami kontrolnymi (nicienie bez kontaktu z insektycydami), a traktowanymi środkami chemicznymi (tab. 5). Zaobserwowane różnice w reakcji testowanych gatunków nicieni na badane insektycydy mogą też wynikać ze swoistych przystosowań obu taksonów do niekorzystnych czynników środowiskowych (Epsky i wsp. 1988; Poinar 1990; Campbell i Gaugler 1991). W przeprowadzonym doświadczeniu oskórek larw J2 mógł chronić larwy inwazyjne nicieni (J3) przed toksycznym działaniem insektycydów, co jednak wymaga potwierdzenia w dalszych badaniach.

Zależność między wpływem neonikotynoidów i insektycydów fosforoorganicznych na nicienie, a czasem ich ekspozycji i różnymi stężeniami zostały potwierdzone przez Chena i wsp. (2003), Petersa i Poullota (2004), Dzięgielewską i Kaup (2007) oraz Uluego i wsp. (2016). Natomiast Nermut i Mráček (2010) zauważyli zależność między stężeniem substancji czynnych zawartych w preparatach, a rozwojem nicieni oraz wskazali na różnice wrażliwości poszczególnych gatunków nicieni, tj. S. feltiae, S. arenarium i S. kraussei na testowane insektycydy. Jednak niektórzy autorzy nie wykazali znaczącego wpływu chloropiryfosu czy fenitrotionu na przeżywalność nicieni owadobójczych np. S. feltiae (Gutiérrez i wsp. 2008). Brak lub minimalny wpływ innych grup chemicznych insektycydów np. fenylopirazoli (fipronilu) i karbaminianów (karbofuran, fenoksykarb) na zdolności infekcyjne larw inwazyjnych nicieni wykazano także w innych badaniach (Gordon i wsp. 1996; García del Pino i Jové 2005; Nermut i Mráček 2010).

Natomiast negatywny wpływ preparatów fosforoorganicznych na aktywność biologiczną nicieni owadobójczych wykazano w badaniach Dzięgielewskiej i Kaup (2007), Uluego i wsp. (2016) oraz Kwizera i Susurluka (2017). Na podstawie wielu badań wykazano, że insektycydy z grupy neonikotynoidów (acetamipryd, imidachlopryd, tiametoksam), pyretroidów (cypermetryna, lambda-cyhalotryna), karbaminianów (karbaryl, oksamyl) i związków fosforoorganicznych (chloropiryfos, fenamifos, fenitrotion, trichlofron, acefat, dimetoat) osłabiają zdolności infekcyjne nicieni owadobójczych zarówno z rodziny Steinernematidae, jak i Heterorhabditidae (Hara i Kaya 1983; Head i wsp. 2000; De Nardo i Grewal 2003; Alumai i Grewal 2004; Gutiérrez i wsp. 2008; Nermut i Mráček 2010).

Większą wrażliwość nicieni z rodzaju Steinernema sp. na działanie badanych insektycydów, w porównaniu do Heterorhabditis sp., potwierdzają badania Dzięgielewskiej i Kaup (2007), w których wykazano znacznie wyższą śmiertelność $S$. feltiae niż $H$. bacteriophora po kontakcie z acetamiprydem i imidachloprydem. Baimey i wsp. (2015) w swojej pracy przedstawili wyższą tolerancję $H$. indica i $H$. sonorensis na fipronil w porównaniu do gatunków nicieni z rodzaju Steinernema sp. Podobnie Ulu i wsp. (2016) uzyskali wyniki świadczące o większej tolerancji fosetylu przez $H$. bacteriophora niż S. carpocapsae. Jednak wyniki badań Atwa i wsp. (2013) wskazują na wyższą wrażliwość $H$. bacteriophora na metomyl w porównaniu do Steinerne$m a$ sp. Z przeprowadzonych badań wynika, że poszczególne gatunki nicieni wykazują różną wrażliwość na insektycydy. Gordon i wsp. (1996) wykazali większą wrażliwość

Tabela 5. Średnia wydajność końcowa Steinernema feltiae i Heterorhabditis bacteriophora po kontakcie z testowanymi insektycydami (Mospilan 20 SP, Dursban 480 EC) w różnych stężeniach [\%]

Table 5. Average final production of Steinernema feltiae and Heterorhabditis bacteriophora invasive larvae after contact with tested insecticides (Mospilan 20 SP, Dursban 480 EC) in various concentrations [\%]

\begin{tabular}{c|c|c|c|c}
\hline \multirow{2}{*}{$\begin{array}{c}\text { Stężenie } \\
\text { preparatu } \\
\begin{array}{c}\text { Concentration } \\
{[\%]}\end{array}\end{array}$} & $\begin{array}{c}|c| \\
\text { Steinernema feltiae }\end{array}$ & \multicolumn{2}{c}{ Heterorhabditis bacteriophora } \\
\cline { 2 - 5 } & svarage amount of invasive nematodes larvae J3 [pcs] & \multicolumn{2}{c}{$\begin{array}{c}\text { średnia liczba larw inwazyjnych nicieni J3 [szt.] } \\
\text { avarage amount of invasive nematodes larvae J3 [pcs] }\end{array}$} \\
\cline { 2 - 5 } & Mospilan 20 SP & Dursban 480 EC & Mospilan 20 SP & Dursban 480 EC \\
\hline 0 & 27435 & 27435 & 134758 & 134758 \\
\hline 0,03 & 23237 & 0 & 130920 & 99233 \\
\hline 0,1 & 24941 & 0 & 126000 & 89000 \\
\hline 0,3 & 21728 & 0 & 114020 & 80210 \\
\hline 0,5 & 0 & 0 & 115529 & 0 \\
\hline 1 & 0 & 0 & 108135 & 0 \\
\hline
\end{tabular}


S. feltiae na karbofuran w porównaniu z $S$. carpocapsae. Gutiérrez i wsp. (2008) udowodnili różnice w tolerancji cypermetryny na poziomie szczepów, szczep Rioja-rodzimy $S$. feltiae był bardziej wrażliwy od szczepu $S$. feltiae pochodzącego z komercyjnego biopreparatu Entonem ${ }^{\circledR}$. To oznacza, że poszczególne gatunki nicieni, a nawet populacje tych nicieni, mogą w odmienny sposób reagować na środki ochrony roślin zawarte w glebie i wykazywać różną skuteczność w zwalczaniu owadów szkodliwych w systemie zintegrowanym.

\section{Wnioski / Conclusions}

1. Insektycydy zawierające chloropiryfos i acetamipryd mogą negatywnie wpływać na żywotność, zdolności infekcyjne i reprodukcyjne nicieni owadobójczych w zależności od substancji czynnej zawartej w preparacie, stężenia preparatu i czasu ekspozycji nicieni z substancją chemiczną.

2. Przynależność gatunkowa wpływa na żywotność, zdolności infekcyjne i reprodukcyjne nicieni owadobójczych.

3. Wraz ze wzrostem stężenia badanych preparatów (Mospilan 20 SP, Dursban 480 EC) śmiertelność testowanych nicieni $S$. feltiae i $H$. bacteriophora wzrastała, a ich zdolności infekcyjne i reprodukcyjne wprost proporcjonalnie malały.

4. Gatunek H. bacteriophora charakteryzował się większą odpornością na testowane insektycydy (Mospilan 20 SP, Dursban 480 EC) niż S. feltiae.

5. Biopreparaty zawierające nicienie owadobójcze $S$. feltiae i $H$. bacteriophora nie powinny być stosowane jednocześnie z insektycydami opartymi na acetamiprydzie i chloropiryfosie, ani w krótkim czasie po ich aplikacji.

\section{Literatura / References}

Alumai A., Grewal P.S. 2004. Tank-mix compatibility of the entomopathogenic nematodes, Heterorhabditis bacteriophora and Steinernema carpocapsae, with selected chemical pesticides used in turfgrass. Biocontrol Science and Technology 14 (7): 725-730. DOI: $10.1080 / 09583150410001724334$

Atwa A.A., Shamseldean M.M., Yonis F.A. 2013. The effect of different pesticides on reproduction of entomopathogenic nematodes. Turkish Journal of Entomology 37 (4): 493-502.

Baimey H., Zadji L., Afouda L., Moens M., Decraemer W. 2015. Influence of pesticides, soil temperature and moisture on entomopathogenic nematodes from southern Benin and control of underground termite nest populations. Nematology 17 (9): 1057-1069. DOI: $10.1163 / 15685411-00002923$

Bednarek A. 1990. Ecological conditions of biological activity of entomopathogenic nematodes in soil environment of agrocenosis. Rozprawy Naukowe i Monografie 118. Szkoła Główna Gospodarstwa Wiejskiego - Akademia Rolnicza, Warszawa, 108 ss.

Campbell R.L., Gaugler R. 1991. Role of the sheath in desiccation tolerance of two entomopathogenic nematodes. Nematologica 37 (1-4): 324-332. DOI: 10.1163/187529291X00321

Chen S., Han X., Moens M. 2003. Effect of chlorpyrifos on infectivity and survival of Steinernema feltiae. Russian Journal of Nematology $11(1): 1-6$.

De Nardo E.A.B., Grewal P.S. 2003. Compatibility of Steinernema feltiae (Nematoda: Steinernematidae) with pesticides and plant growth regulators used in glasshouse plant production. Biocontrol Science and Technology 13 (4): 441-448. DOI: $10.1080 / 0958315031000124495$

Dzięgielewska M. 2012. Występowanie nicieni owadobójczych z rodziny Steinernematidae i Heterorhabditidae w sadach chronionych i niechronionych chemicznie. [Occurrence of entomopathogenic nematodes of the family Steinernematidae and Heterorhabditidae in orchards chemically protected and unprotected]. Progress in Plant Protection 52 (2): 415-420. DOI: 10.14199/ppp-2012-075

Dzięgielewska M., Kaup G. 2007. Wpływ preparatów układowych aplikowanych doglebowo na aktywność biologiczną nicieni owadobójczych Steinernema feltiae Filipjev i Heterorhabditis megidis Poinar, Jackson. [Effect of systemic preparations applied to soil on the biological activity of entomopathogenic nematodes of Steinernema feltiae Filipjev and Heterorhabditis megidis Poinar, Jackson]. Chemia i Inżynieria Ekologiczna 14 (11): 1167-1173.

Epsky N.D., Walter D.E., Capinera J.L. 1988. Potential role of nematophagus microarthropods as biotic mortality factors of entomogenus nematodes (Rhabditida: Steinernematidae; Heterorhabditidae). Journal of Economic Entomology 81 (3): 821-825. DOI: 10.1093/ jee/81.3.821

García del Pino F., Jové M. 2005. Compatibility of entomopathogenic nematodes with fipronil. Journal of Helminthology 79: $333-337$. DOI: $10.1079 / \mathrm{JOH} 2005294$

Gordon R., Chippett J., Tilley J. 1996. Effects of two carbamates on infective juveniles of Steinernema carpocapsae all strain and Steinernema feltiae Umea strain. Journal of Nematology 28 (3): 310-317.

Gutiérrez C., Campos-Herrera R., Jiménez J. 2008. Comparative study of the effect of selected agrochemical products on Steinernema feltiae (Rhabditida: Steinernematidae). Biocontrol Science and Technology 18 (1): 101-108. DOI: 10.1080/09583150701684267

Hara A.H., Kaya H.K. 1983. Toxicity of selected organophosphate and carbamate pesticides to infective juveniles of the entomogenous nematode Neoaplectana carpocapsae (Rhabditida: Steinernematidae). Environmental Entomology 12 (2): 496-501. DOI: 10.1093/ ee/12.2.496

Head J., Walters K.F.A., Langton S. 2000. The compatibility of the entomopathogenic nematode, Steinernema feltiae, and chemical insecticides for the control of the South American leafminer, Liriomyza huidobrensis. Biocontrol 45: 345-353. DOI: 10.1023/ A:1009986217310

Jamiołkowska A., Hetman B., Skwaryło-Bednarz B., Kopacki M. 2017. Integrowana ochrona roślin w Polsce i Unii Europejskiej oraz prawne podstawy jej funkcjonowania. Praca przeglądowa. Agronomy Science 72 (1): 103-111. DOI: 10.24326/as.2017.1.8 
Jaworska M., Dudek B. 1992. A survey of insect parasitic nematodes In the soil of some crops. Zeszyty Naukowe Akademii Rolniczej im. Hugona Kołłątaja w Krakowie 267 (20): 131-147.

Kwizera V., Susurluk I.A. 2017. Evaluation of the effects of some insecticides based on neonicotinoids on entomopathogenic nematodes, Steinernema feltiae and S. carpocapsae. Invertebrate Survival Journal 14 (1): 375-378. DOI: 10.25431/1824-307X/isj.v14i1. $375-378$

Laznik Ž., Trdan S. 2017. The influence of herbicides on the viability of entomopathogenic nematodes (Rhabditida: Steinernematidae and Heterorhabditidae). International Journal of Pest Management 63 (2): 105-111. DOI: 10.1080/09670874.2016.1227882

Laznik Ž., Vidrih M., Trdan S. 2012. The effects of different fungicides on the viability of entomopathogenic nematodes Steinernema feltiae (Filipjev), S. carpocapsae Weiser, and Heterorhabditis downesi Stock, Griffin \& Burnell (Nematoda: Rhabditida) under laboratory conditions. Chilean Journal of Agricultural Research 72 (1): 62-67.

Matuska J., Kamionek M. 2008. Występowanie nicieni owadobójczych Heterorhabditis megidis (Poinar, Jackson and Klein 1987) w naturalnych ekosystemach województwa świętokrzyskiego. [Occurrence of entomopathogenic nematodes Heterorhabditis megidis (Poinar, Jackson and Klein 1987) in the natural ecosystems of the Świętokrzyskie Province]. Ecological Chemistry and Engineering 15 (4-5): 383-387.

Nermut J., Mráček Z. 2010. The influence of pesticides on the viability and infectivity of entomopathogenic nematodes (Nematoda: Steinernematidae). Russian Journal of Nematology 18 (2): 141-148.

Peters A., Poullot D. 2004. Side effects of surfactants and pesticides on entomopathogenic nematodes assessed using advanced IOBC guidelines. International Organisation for Biological and Integrated Control/West Palearctic Regional Section Bulletin 27 (6): 67-72.

Pisa L., Goulson D., Yang E.C., Gibbons D., Sánchez-Bayo F., Mitchell E., Aebi A., van der Sluijs J., MacQuarrie C.J.K., Giorio C., Long E.Y., McField M., Bijleveld van Lexmond M., Bonmatin J.M. 2017. An update of the Worldwide Integrated Assessment (WIA) on systemic insecticides. Part 2: impacts on organisms and ecosystems. Environmental Science and Pollution Research. DOI: 10.1007/ s11356-017-0341-3

Poinar G.O. Jr. 1990. Taxonomy and biology of Steinernematidae and Heterorhabditidae. s. 23-61. W: Entomopathogenic Nematodes in Biological Control (R. Gaugler, H.K. Kaya, red.). CRC Press, Boca Raton, 381 ss. ISBN 9781351088640

Ropek D., Nicia P. 2008. Owadobójcze grzyby i nicienie w glebach górskich oligotroficznych łąk niskoturzycowych. [Entomopathogenic fungi and nematodes in oligotrophic low sedge fen soils]. Ecological Chemistry and Engineering 15 (1-2): 133-138.

Rozkrut D. (red.). 2020. Rocznik Statystyczny Rolnictwa. Główny Urząd Statystyczny, Warszawa, 449 ss.

Sunanda M., Chandra Sekhara Rao J., Neelima P., Simhachalam G. 2016. Toxicity and effects of chlorpyrifos in a non-target organism (Fish) - A review. Journal of Atoms and Molecules 6 (3): 966-976.

Tomalak M. 2005. Potentials of entomopathogenic nematodes for biological control of selected pests insects infesting urban trees. Insect pathogens and insect parasitic nematodes. International Organisation for Biological and Integrated Control/West Palearctic Regional Section Bulletin 28 (3): 3-7.

Tumialis D., Pezowicz E., Skrzecz I., Mazurkiewicz A., Maszewska J., Jarmuł-Pietraszczyk J., Kucharska K. 2016. Occurrence of entomopathogenic nematodes in Polish soils. Ciência Rural 46 (7): 1126-1129. DOI: 10.1590/0103-8478cr20151542

Ulu T.C., Sadic B., Susurluk I.A. 2016. Effects of different pesticides on virulence and mortality of some entomopathogenic nematodes. Invertebrate Survival Journal 13 (1): 111-115. DOI: 10.25431/1824-307X/isj.v13i1.111-115

White G.F. 1927. A method for obtaining infective nematode larvae from cultures. Science 66 (1709): 302- 303. DOI: 10.1126/ science.66.1709.302-a 